\title{
The Effects of Assets and Debts on Profit Among Advertising, Printing and Media Listed Firms in Indonesia
}

\author{
Wahyu Indah Mursalini ${ }^{1}$, Witra Maison ${ }^{2}$, Juita Sukraini $^{3}$, Nidia Anggraini Das ${ }^{4}$, Afniyeni ${ }^{5}$ \\ 1,2,3,4,5 University Mahaputra Muhammad Yamin \\ *Corresponding author E-mail: wahyuindah771@gmail.com,witra2263@gmail.com, juitasukraini@gmail.com, \\ *Corresponding author Email : dasnidiaanggreni@gmail.com
}

\begin{abstract}
The purpose of this study is to determine the effect of assets and debts to company profit. Assets and Debts are the deciding variables to make a company profit. Debt is inversely proportional to profit. Therefore, any company's management must be able to manage the assets and debt of the company to increase corporate profit. Need to explain why Sub Sector Company Advertising Printing and Media on Indonesia Stock Exchange is studies here. Based on the results of research, asset and debt have a significant effect to the profit of Sub Sector Company Advertising Printing and Media listed on Indonesia Stock Exchange. This is evidenced by statistical analysis. The researcher suggests the inclusion of control variables such as economic growth and capital structure so that the results of research can assist investors in assessing the company. Increase the period of research into 10 years, so that the results of research can describe the condition of the company for the long term and can pay attention to the business cycle. In addition, the study could be replicated on other sectors and comparative analysis could be done accordingly.
\end{abstract}

Keywords: Management, Asset, Debt, Profitability.

\section{Introduction}

Most companies must have a good performance in order for the company to survive to face business competition. Performance can be assessed from aspects of management, finance, and other aspects (1). One of the advantages that need to be developed by the company is the financial performance, especially in the field of managing the amount of assets and debt. Assets are the most important source and wealth of a company, both tangible and intangible assets (2). Debt is a source of funding for both short-term and long-term debt (3).

The source of the company fund comes from its own capital and loan capital. Own capital is obtained from equity while loan capital comes from debt (4). Both assets and debts have a different effects on the value of the company. If Asset increased then the company's profit will increase as well, while the debt if increased then the company's profits will be reduced. As such, any profits generated by using debts must prioritize payment of the debts (5). But if the company does not use debts as the source of funding then the company's survival will be disrupted in achieving maximum profit. Therefore, corporate managers must be able to manage these debts so as not to cause harm to the stakeholders.

As such, information on profitability is very useful for both owners and investors. Therefore the decisions related to the management of assets and debt will greatly determine the company's profit.

\section{Literature Review and Hypotheses Development}

Financial management is management-related tasks as a financial manager in a business enterprise (6). Finance managers actively manage the financial affairs of various types of businesses, related to finance or non-financial, personal or public, large or small, profit or non-profit (7).

\subsection{Profitability}

High earnings changes indicate the profit earned by the company is high, so the dividend rate of the company is also high (8). The effectiveness or efficiency of a business unit in general can be seen in the profits he achieved (9). This will affect investment decisions of investors who expect the funds invested into the company to give a high rate of return.

The main goal of any company is to maximize profits (10). The definition of operating profit is the difference between the realized revenue arising from transactions over a period with the costs associated with the income (11). The size of the profit depends heavily on the accuracy of revenue and cost measurement.

Profitability is a description of the performance of management in managing the company (12). Profitability of a company is measured from the ability of companies to use their assets productively, by comparing the profit earned in a period with the amount of the company's assets (13). Profitability is the ability of a company to earn profits in relation to sales, total assets and own capital (14). Good company performance will increase company value (15). 


\subsection{The Relationship between Asset and Company Profit}

Assets can be classified into two main parts: current assets and non-current assets (16). Current assets are cash and others that can be expected to be cashed or convertible into cash, for sale or consumer in a subsequent period (maximum of one year or in normal business turnover). Presentation of items on current assets in the balance sheet is based on their liquidity sequence, so the presentation starts from the most liquid assets up to the least liquid assets (17).

Assets are resources owned by business or business entity. These resources can be physical or economic. Assets have potential benefits in the future, the potential benefits can be in the form of productive things that can generate cash or cash equivalents (18). Assets are future economic benefits that can be realized or acquired by a particular entity as a result of past transactions or events (19). On Assets as producers of goods and services, can be beneficial and can be exchanged for other assets or pay off obligations (debt). And earnings can be obtained through assets invested by shareholders. Good asset management will increase the company's attractiveness to investors (15). Increased attractiveness of the company makes the company more interested investors (20).

There are several ways to acquire assets, such as by way of production or self-built, assets can be obtained by purchase and can be obtained by the exchange of assets and donations from other parties (2). If examined, ownership of assets is not only about property-owned assets but also other rights such as lease rights, building rights, collecting rights, use rights or others. Differences in ownership rights will affect the type of item and asset classification in the financial statements (21). As the types of assets owned by a company have value for the company, the following hypothesis is proposed:

$\mathbf{H}_{1}$ : Assets are positively related to company profit.

\subsection{The Relationship between Debt and Company Profit}

Debts are all liabilities to other parties that have not been fulfilled, where this debt is a source of funds or capital companies that come from creditors (22). Debt or corporate liability can be differentiated into current liabilities (short-term debt) and long-term debt (23). In a simple sense a debt can be defined as all current corporate liabilities to others arising from past events and must be resolved in the future.

Debt policy is a policy of funding committed by the management company in order to obtain funding sources to finance the operating activities of the company (24). The company is considered risk if it has a large amount of debt in the capital structure, but if the company uses small debts or not at all then the company is considered unable to utilize additional external capital that can improve the company operation (4).

Debt policies are often measured using a Debt to Equity Ratio that reflects a company's ability to use all of its obligations indicated by some portion of its own capital used to repay debt (25). The higher the level of corporate debt then the possibility of financial risk and corporate failure will also be higher (26). Because the debt is all the financial obligations of the company to other parties that have not been fulfilled and must be paid in accordance with the term of credit, the following hypothesis is proposed: $\mathbf{H}_{2}$ : Debts are negatively related to company profit.

\section{Methods}

The population in this research is the company listed on Indonesia Stock Exchange for five years period. The population in this research is 15 companies. The criteria used to select the sample are as follows: Printing and media sub-sector advertising services companies listed on the Indonesia Stock Exchange, that publishes consecutive financial statements ending on 31 December and companies that have complete financial data to calculate the vari- ables in this study during the observation period that is the year 2012-2016.

Based on these criteria, the sample of this study is as many as 11 companies. The variables used in this study are profits, assets and debt, where profit is the dependent variable while assets and debt are independent variables. A regression model was developed after using Generalized Least squre (GLS) method and conducting classical assumsion test.

\subsection{Data Collection}

Asset is the company wealth that can be seen in the statement of changes in financial position. Debt is a source of funding for the company which can be seen in the statement of changes in the financial position of passiva section. While profit is an excess of revenue over operating expenses that can be seen in the income statement of the company.

\subsection{Data Analysis}

Data analysis can be done by statistical test using Liniear Regression, with the help of Eviews program, that is:

\section{$\mathbf{Y}=\mathbf{a}+\mathbf{b}_{1} \mathbf{X}_{1}+\mathbf{b}_{2} \mathbf{X}_{2}+\mathbf{e}_{1}$}

Where: $\mathrm{Y}$ is Net Profit, a is a constant, $\mathrm{b}$ is Coefficient, $\mathrm{X}_{1}$ is Asset and $\mathrm{X}_{2}$ is Debt and $\mathrm{e}_{1}$ is Residual.

Before the regression model is used to draw conclusions, the model must be tested first using Generalized Least Square (GLS) method and classical assumption test.

\section{Results (or Results and Discussion)}

Based on the formulation of the problem and the hypothesis, the purpose of this study is to analyze the influence of assets and debt on profitability of Sub-Sector Companies Advertising Printing and Media listed on the Indonesia Stock Exchange. The results obtained can be seen in table 4.1 below:

Table 4.1 Classical Assumption Correction

\begin{tabular}{|c|c|c|c|c|}
\hline Variable & Coefficient & Std. Error & $\mathrm{t}$-Statistic & Prob. \\
\hline & & & & \\
\hline $\mathrm{C}$ & 111.2561 & 77.69118 & 1.432030 & 0.1595 \\
\hline $\mathrm{X} 1$ & 15.25789 & 3.434950 & 4.441953 & 0.0001 \\
\hline $\mathrm{X} 2$ & -19.13905 & 1.924857 & -9.943105 & 0.0000 \\
\hline & & & & \\
\hline & Effects Spec & ification & & \\
\hline & & & & \\
\hline Cross-section fixed & mmy variable & & & \\
\hline & & & & \\
\hline & & atistics & & \\
\hline & Weignted s & atistics & & \\
\hline & & & & \\
\hline R-squared & 0.821913 & \multicolumn{2}{|c|}{ Mean dependent var } & 32.03409 \\
\hline $\begin{array}{l}\text { Adjusted R- } \\
\text { squared }\end{array}$ & 0.771031 & \multicolumn{2}{|c|}{ S.D. dependent var } & 28.02056 \\
\hline S.E. of regression & 7.872145 & \multicolumn{2}{|c|}{ Sum squared resid } & 2602.768 \\
\hline F-statistic & 16.15329 & \multicolumn{2}{|c|}{ Durbin-Watson stat } & 1.917816 \\
\hline Prob(F-statistic) & 0.000000 & & & \\
\hline & & & & \\
\hline & \multicolumn{2}{|c|}{ Unweighted Statistics } & & \\
\hline & & & & \\
\hline R-squared & 0.556487 & \multicolumn{2}{|c|}{ Mean dependent var } & 20.10473 \\
\hline Sum squared resid & 2844.480 & \multicolumn{2}{|c|}{ Durbin-Watson stat } & 1.959650 \\
\hline & & & & \\
\hline & & & & \\
\hline
\end{tabular}




\section{Discussion (or Results and Discussion)}

Based on the data testing process using the Eviews program obtained summary test results as follows: Each coefficient of each independent variable has a slope that will explain the direction of influence of each independent variable to the dependent variable that will be formed into a regression equation with correction method using General least square model as seen below:

$\mathrm{Y}=111.2561+15.25789 \mathrm{X}_{1}-19.13905 \mathrm{X}_{2}$

From the above equation obtained a constant value of 111.2561 which defines that if the independent variable is zero then the profit value is a constant of 111.2561. Asset has a coefficient of 15.25789 indicates that any increase in Asset amount of $1 \%$ will result in increased profit of the company of 15.25789 (Asset has a positive effect on profit). Debt has a coefficient of -19.13905 indicates that any increase in debt of $1 \%$ will result in a decrease in company profit of 0.0301312 (debt has a negative effect on profit). Testing is done using a level of confident of $95 \%$. The results show that the significant value is <Alpha (0.05). From the test conducted showed that a significant value of 0.0000 which is smaller than the significant level of 0.05 . The Adjusted R Square is equal to $0,771(77,1 \%)$ meaning the assets and debts greatly affect profit of Sub Sector Service Advertising Printing and Media businesses.

As such, the first hypothesis is accepted and the researcher concludes that Asset have significant effect to the profit of the company. The value of $t$ statistic is 4.4419 and the significant value 0.0001 is less than $\alpha=0.05$. This shows that there is a direct relationship between asset to profit. The second hypothesis in this study is also accepted because there is a negative influence between debt with the profit of the company. The value of $t$ statistic is -19.943105 and the significant value 0.0001 is less than $\alpha=$ 0.05 . This shows that debt is in the opposite direction with Profit. The test results that used the F Test indicate that assets and debts have significant effect on the profitability of the company with the F statistic being 16,153 and the significant value 0.0001 is less than $\alpha=0.05$.

\section{Conclusion and Recommendation}

The purpose of this study is to determine the effect of assets and debt to profit of the company. Assets may be useful directly or indirectly and are productive. Debt is a source of funds or capital derived from the creditor. At a time when economic conditions decline, having large debts will cause failure for the company to pay principal and interest on the loan. Conversely, when the economic conditions increase, having large amounts of debt will be profitable for the company that want to profit. The results of this study support previous research that indicated that debt has an effect and is inversely proportional to profit (27).

Based on the results of statistical analysis, the researched concluded that assets and debts significantly influence profit either partially or simultaneously. This shows that assets and debts need to be managed properly efficiently and effectively in accordance with the rules governing the concept of assets and debt in order to increase profit of the company.

Thus, firms must be able to manage debt levels at a level of balanced cost and benefits. Assets and debt are the deciding variables to make a company profit (4). Therefore, the company's management must be able to manage the assets and debt in order to increase profits. It is proven that based on the results of asset analysis and debt analysis significantly affect the profit of Sub Sector Advertising Printing and Media Companies listed on the Indonesia Stock Exchange. An increase in profits can illustrate the viability of a company.

The researcher suggests the iclussion of control variables such as economic growth and capital structure and increase time period of research become 10 year, so that result of research can describe condition of company for long term and company can pay atten- tion to business cycle. In addition, the study could be replicated on other sectors and comparative analysis could be done accordingly.

\section{Conflict of Interest}

There is no conflict in this study.

\section{Acknowledgments}

The author acknolwdge the funding support from the Rector and Dean of Faculty of Economics University Mahaputra Muhammad Yamin in this research.

\section{References}

[1] Khalfallah M, Moschetto B-L, Teulon F. Evaluation Of The Profitability Of Companies Financed By Venture Capital (CVC) Listed On The French Market. J Appl Bus Res. 2014;30(2):313-28.

[2] Hsieh C, Wu CY. Working capital management and profitability of publicly traded Chinese Companies. Asia Pacific J Econ Bus. 2013;17(1):1-11.

[3] Nimer M Al, Warrad L, Omari R Al. The impact of liquidity on Jordanian Banks profitability Through return on assets. Interdiscip J Contemp Res Bus. 2013;5(7):70-7.

[4] Mursalini WI, Husni T, Hamidi M. Analysis of funding, working capital turnover, liquidity and sales growth to profitability. Adv Sci Lett. 2017;23(9):8341-6.

[5] Mursalini WI, Husni T, Hamidi M, Ridwan E, Arfimasri. Analysis of cash conversion cycle and sales growth to liquidity. In: Annual conference on economics, business, accounting and social sciences ( ACEBASS ) 2017, Theme sustainability development in achieving economic independence. LPTIK Universitas Andalas; 2017. p. 266-71

[6] Singh S, Jain, Yadav S. Financial management analysis of profitability of selected Idustries in India: Empirical research findings. J Financ Manag Anal. 2013;26(1):75-95.

[7] Bhanawat H, Somani PR. Outcome of receivables management on working capital \& profitability: Case study of selected cement companies. Int J Mark Financ Serv Manag Res. 2016;5(9):1-10.

[8] Agha H. Impact of working capital management on profitability. Eur Sci J. 2014;10(1):374-81.

[9] Altan M, Sekeroglu G. The effects of working capital financing strategies on profitability: A Research on Companies Listed on ISE. J Inst Soc Sci. 2013;30(1):223-8.

[10] Gill A, Biger N, Mathur N. The effect of capital structure on profitability: Evidence from the united states. Int $J$ Manag. 2011;28(4):3-15.

[11] Baragar F, Chernomas R. Profits from Production and Profits from Exchange: Financialization, Household Debt and Profitability in 21st-Century Capitalism. Sci Soc. 2012;76(3):319-39.

[12] Bolaji AA, Olukayode ME, Abdulmaliq AA. Strategic development financing mix and economic growth in Nigeria. Pakistan $\mathrm{J}$ Bus Econ Rev. 2011;1(1):1-13

[13] Aminu Y, Zainudin N. An analysis of proposed framework on impact of working capital management on the profitability of selected manufacturing companies listed on the Nigerian Stock Exchange. J Econ Behav Stud. 2012;4(12):730-6.

[14] Ngwenya S. The relationship between working capital management and profitability of companies listed on the Johannesburg Stock Exchange. J Mod Account Audit. 2012;8(8):1204-13.

[15] Afrifa GA. Net working capital, cash flow and performance of UK SMEs. Rev Account Financ. 2016;15(1):21-44.

[16] Arshad Z, Gondal MY. Impact of working capital managemet on profitability a case of the pakistan cement Industry. Interdiscip J Contemp Res Bus. 2013;5(2):384-91.

[17] Aysun U. Capital flows, Maturity mismatches, and profitability in emerging markets: Evidence from bank level data. J Dev Areas. 2012;46(1):211-39.

[18] Valipour H, Moradi J, Farsi FD. The Impact of company characteristics on working capital management. J Appl Financ Bank. 2012;2(1):105-25

[19] Tauringana V, Afrifa GA. The relative importance of working capital management and its components to SMEs' profitability. J Small Bus Enterp Dev. 2013;20(3):453-69. 
[20] Ammons JL, Gosman ML. Cautions when using working capital metrics to assess firms Financial health. J Int Acad Case Stud. 2012;18(3):11-5.

[21] Saghir A, Hashmi FM, Hussain MN. Working capital management and profitability: Evidence from India an empirical study. Interdiscip J Contemp Res Bus. 2011;3(8):1092-105.

[22] Rajdev MA. Working capital management of Makson Healthcare PVT Ltd: A trade-off between liquidity and profitability, an empirical study. Int Ref Res J. 2013;IV(3):87-94.

[23] Jamalinesari S, Soheili H. The Relationship between the Efficiency of Working Capital Management Companies and Corporate Rule in Tehran Stock Exchange. Soc Behav Sci. 2015;205(May):499-504.

[24] Madishetti, S, Kibona D. Impact of accounts receivables management on the profitability of SMEs in Tanzania. Asian J Res Bank Financ. 2013;3(2):1-15.

[25] Makori DM, Jagongo A. Working capital management and firm profitability: Empirical evidence from manufacturing and construction firms listed on Nairobi Securities Exchange , Kenya. Int J Account Tax. 2013;1(1):1-14.

[26] Pimplapure VU, Kulkarni PP. Working capital management: Impact of profitability. SCMS J Indian Manag. 2011;Oct(1):53-60.

[27] Yazdanfar D. Profitability determinants among micro firms: evidence from Swedish data. Int J Manag Financ. 2013;9(2):151-60. 